stress on intrauterine growth is small compared with that of smoking. The provision of social support is not in itself likely to improve outcome in terms of fetal growth. If unrestricted fetal growth is to be achieved pregnant women should stop smoking. The effects of alcohol on fetal growth in those who smoke require further investigation, but for non-smokers there is little need to be concerned that intake within the range found in our study is harmful. Finally, we emphasise that our results apply only to fetal growth expressed as a continuous variable and should not be extrapolated freely to low birth weight or to other fetal outcomes such as mortality, congenital malformation, and preterm delivery. Possibly stress factors have more influence on gestational age, which the present analysis was not designed to detect.

We thank Professors R R Trussell and G V P Chamberlain and the clinic staff for facilitating the study; Rebecca Macnair for carrying out the pilot study; Professor E Paykel for advice on the measurement of stress; and all the interviewers. Financial support was received from a consortium of American tobacco companies.

I Williams RL, Chen PM. Identifying the sources of the recent decline in perinatal mortality rates in California. $N$ Engl f Med 1982;306:207-14. Dunn HG. Social aspects of low birthweight. Can Med Assoc $\mathcal{F} 1984 ; 130$ $1131-40$

3 United States Surgeon General. The health consequences of smoking for women report. Washington: United States Department of Health and Human Services, Public Health Service, Office of the Assistant Secretary for Health Office on Smoking and Health, 1980.

4 Paul AA, Southgate DAT. McCunce and Widdowson's the composition of foods. 4th ed. London: HMSO, 1978

5 Office of Population Censuses and Surveys. Classification of occupations. London: HMSO, 1980.

6 Goldberg DP, Hillier VF. A scale version of the general health questionnaire. Psychol Med 1979;9:139-45.

7 Paykel ES, Myers KJ, Dienelt MN, Lerman GL, Lindenthal JJ, Pepper MP. Life events and depression: a controlled study. Arch Gen Psychiatry 1969;21:753-60.

8 Eysenck HJ, Eysenck SBG. Manual for the Eysenck personality inventory. London: London University Press, 1964

9 Keen DV, Pearse RG. Birthweight between 14 and 42 weeks' gestation. Arch Dis Child 1985;60:440-6.

10 Carr-Hill R, Pritchard C. Development and exploitation of empirical birthweigh standards. London: Macmillan Press, 1985

11 SAS Institute. SAS user's guide. Cary, North Carolina: SAS Institute, 1985.

12 Gardner MJ, Altman DG. Confidence intervals rather than $P$ values: estimation rather than hypothesis testing. Br Med $\mathcal{J}$ 1986;292:746-50.
13 Carr-Hill R, Campbell DM, Hall MH, Meredith A. Is birth weight determined genetically? BrMed f 1987;295:687-9.

14 Rush D, Cassano P. Relationship between cigarette smoking and social class to birthweight and perinatal mortality among all births in Britain, 5-11 April 1970. F Epidemiol Community Health 1983;37:249-55.

15 Yerushalmy J. The relationship of parents' cigarette smoking to outcome of pregnancy-implications as to the problem of inferring causation from observed associations. Am I Epidemiol 1971;93:443-56.

16 Meridith HV. Relation between tobacco smoking of pregnant women and body size of their pregnancy: a compilation and synthesis of published body size of their pregnancy: a com
studies. Hum Biol 1975;47:451-72.

17 Rubin DH, Krasilnikoff PA, Leventhan JM, Weile B, Berget A. Effect of passive smoking on birth-weight. Lancet 1986;ii:415-7.

18 Trichopoulos D. Passive smoking, birthweight and oestrogens. Lancet 1986;ii: 743 .

19 Lee PN. Misclassification as a risk factor in passive smoking risk. Lance 1986 ;ii: 867 .

20 Martin TR, Bracken MB. Association of low birth weight with passive smoke exposure in pregnancy. Am $\mathcal{F}$ Epidemiol 1986;124:633-42.

21 Royal College of Psychiatrists. Alcohol: our favourite drug. London: Tavistock Publications, 1986.

22 Barrison IG, Waterson EJ, Murray-Lyon IM. Adverse effects of alcohol in pregnancy. Br f Addict 1985;80:11-22.

23 Wright JT, Waterson EJ, Barrison IG, et al. Alcohol consumption, pregnancy and low birthweight. Lancet 1983;i:663-5.

24 Kline J, Stein Z, Hutzler M. Cigarettes, alcohol and marijuana: varying associations with birthweight. Int $\mathcal{Z}$ Epidemiol 1987;16:44-51.

25 Sulaiman ND, Florey C duV, Taylor DJ, Ogston SA. Alcohol consumption in Dundee primigravidas and its effect on outcome of pregnancy. Br Med $\mathcal{J}$ Dundee primigra

26 Watkinson B, Fried PA. Maternal caffeine use before, during and after pregnancy and effects upon offspring. Neurobehavioural Toxicology and Teratology 1985;7:9-17.

27 Linn S, Schoenbaum SG, Monson RR, Rosner B, Stubblefield PG, Ryan KJ No association between coffee consumption and adverse outcomes of pregnancy. $N$ Engl f Med 1982;306:141-5

28 Habicht J-P, Lechtig A, Yarbrough C, Klein RE. Maternal nutrition, birthweight and infant mortality. In: Elliott $\mathrm{K}, \mathrm{Knight} \mathrm{J}$, eds. Size at birth Amsterdam: Elsevier, 1974:353-70. (Ciba Foundation Symposium 27.)

29 Baird D. Public health aspects of low birthweight. WHO Tech Rep Ser $1961 ;$ No 217

30 Picone TA, Allen LH, Olsen PN, Ferris ME. Pregnancy outcome in N American women. 2. Effects of diet, cigarette smoking, stress and weight gain on placentas, and on neonatal physical and behavioural characteristics. Am f Clin Nutr 1982;36:1214-24.

31 Chalmers B. Psychosocial factors and obstetric complications. Psychol Med 1983;13:333-9.

32 Norbeck JS, Tilden VP. Life stress, social support, and emotional disequilibrium in complications of pregnancy: a prospective, multivariate study. 7 Health Soc Behav 1983;24:30-46.

33 Stein A, Campbell EA, Day A, McPherson K, Cooper PJ. Social adversity, low birth weight, and preterm delivery. BrMed f 1987;295:291-3.

34 Newton RW, Hunt LP. Psychosocial stress in pregnancy and its relation to low birth weight. Br.Med $\mathcal{J} 1984 ; 288: 1191-4$.

35 Newton RW, Webster PAC, Binu PS, Maskrey N, Phillips AB. Psychosocial stress in pregnancy and its relation to the onset of premature labour BrMed f 1979;ii:411-3.

36 Istvan J. Stress, anxiety and birth outcomes: a critical review of the evidence. Psychol Bull 1986;100:331-48.

Accepted 24 fanuary 1989

\section{Methotrexate dosage in patients aged over 50 with psoriasis}

\author{
G M Fairris, A G Dewhurst, J E White, \\ M J Campbell
}

Royal South Hants

Hospital, Southampton SO9 4PE

G M Fairris, MRCP, senior registrar in dermatology A G Dewhurst, MRCP, senior registrar in medicine

J E White, FRCP, consultant dermatologist

Medical Statistics and Computing, Southampton General Hospital, Southampton SO9 4XY M J Campbell, PHD, senior lecturer

Correspondence to:

Dr Fairris.

Br.Med f 1989;298:801-2
Methotrexate has been used for over 20 years to treat severe psoriasis that cannot be adequately controlled by other means. The recommended dose is $10-25 \mathrm{mg}$ orally once a week. ' The drug is well absorbed and is excreted mainly in the urine. It inhibits dihydrofolate reductase, and its most dangerous side effect is myelosuppression, which is partly dose related. We observed that psoriasis in elderly patients could be controlled with less than the recommended dose and investigated some of the factors associated with the dose needed.

\section{Patients, methods, and results}

We identified 23 patients aged over 50 who were treating their psoriasis with methotrexate. All were taking the drug because their psoriasis could not be adequately controlled by topical treatment, etretinate, or psoralens and ultraviolet $\mathrm{A}$. The minimum therapeutic dose of methotrexate was established in all patients by reducing their weekly dose until their disease relapsed. We then increased the dose at intervals of one or two months until the psoriasis was controlled to the patient's satisfaction. The patient's age, weight, height, and concomitant drug treatment were noted. Venous blood was taken to measure haemoglobin concentration, mean corpuscular volume, white cell count, platelet count, and plasma urea and creatinine concentrations. The predicted creatinine clearance was then calculated ${ }^{3}$ :

Predicted creatinine clearance $=$

$(140-$ age $) \times($ weight in $\mathrm{kg}) \times(1.23$ for men $)$

\section{Serum creatinine in $\mu \mathrm{mol} / \mathrm{l}$}

The data were analysed with Pearson's correlation and linear regression. Fourteen patients were men and nine women. Their age ranged from 50 to 93 , weight from 43 to $110 \mathrm{~kg}$, and plasma creatinine concentration from 56 to $139 \mu \mathrm{mol} / \mathrm{l}$.

A significant correlation was found between the minimum therapeutic dose of methotrexate and both predicted creatinine clearance $(\mathrm{r}=0.76, \mathrm{p}<0.001)$ (figure) and age $(\mathrm{r}=-0.74, \mathrm{p}<0.001)$. The relation between dose and predicted creatinine clearance was shown by the linear regression equation:

Dose $=1 \cdot 25+(0 \cdot 157 \times$ predicted creatinine clearance $)$

Age and predicted creatinine clearance are clearly related, and putting age into the prediction equation 


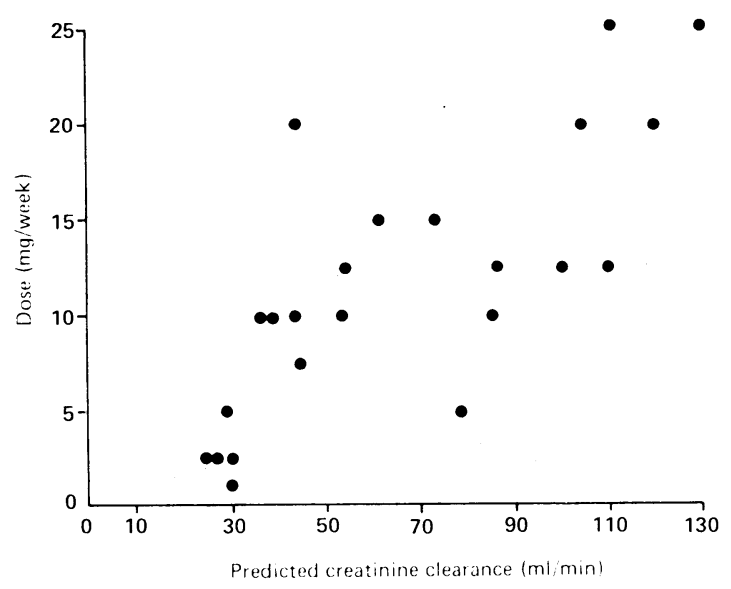

Weekly therapeutic dose of methotrexate plotted against predicted creatinine clearance $(r=0 \cdot 76, \quad p<0 \cdot 001)$. Dose $=1 \cdot 25+(0 \cdot 157 \times$ predicted creatinine clearance)

resulted in minimal improvement in the association $\left.\mathrm{F}_{1,20}=2 \cdot 4, \mathrm{p}>0 \cdot 01\right)$.

\section{Comment}

The dose of methotrexate needed to control severe psoriasis in patients over 50 was found to decrease with decreasing predicted creatinine clearance and increasing age. Six of the 10 subjects aged over 70 required less than the recommended dose of methotrexate.' Four patients aged over 80 were adequately treated with no more than $2.5 \mathrm{mg}$ of methotrexate a week. The rate at which methotrexate clears from the serum correlates with creatinine clearance, ${ }^{+}$and we believe that the progressive deterioration in creatinine clearance associated with the natural aging process is the most likely explanation of our findings.

Methotrexate is particularly useful in frail elderly patients with widespread psoriasis whose physical infirmities prevent the use of other treatments. Prior calculation of the therapeutic dose of methotrexate may allow doctors to treat such patients more confidently and safely.

We thank Dr B J Leppard and Dr P G Goodwin for permission to investigate patients under their care and Mrs P Perkins for technical help.

1 Walker G. ABI'l duta she't compendium 1988-89. London: Datapharm Publications, 1988:743

2 Bleyer WA. Clinical pharmacology: guidelines for the clinical use of methotrexate. In: Hall RR. A comprehensive guide to the therapeutic use of methotrexat in hladder cuncer. New York: Castlereagh Press, 1983:51-69.

3 Cockeroft DW, Gault $\mathrm{MH}$. Prediction of creatinine clearance from serum creatinine. Nephron 1976;16:31-11.

+ Kristensen LO, Weismann K, Hutters L. Renal function and the rate of disappearance of methotrexate from serum. Liur f Clin Pharmacol 1975:8: $+39-4+$

5 Rowe JW, Andres R, Tobin JD, Norris AH, Shock NW. The effect of age on creatunine clearance in men: a cross-sectional and tongitudinal study creatunine clearance in men:

Aciepted 8 December 1988

\section{Prevalence of reflex anal dilatation in 200 children}

\section{A Stanton, R Sunderland}

Detecting cases of child sexual abuse is often difficult. Reflex anal dilatation has been described as a sign of anal abuse in children.' Although a study has been conducted at a specialist centre, ${ }^{2}$ there are no reports on the prevalence of reflex anal dilatation in unselected clinic populations or in "normal" children. We looked at the prevalence of reflex anal dilatation in children attending community child health clinics and outpatient departments.

\section{Subjects, methods, and results}

We looked for reflex anal dilatation in 200 consecutive children who were attending for routine examination in community health clinics, as new patients in a district general hospital's paediatric clinic, or as patients in a renal clinic. Children with lesions of the spinal cord were excluded. Carers were asked about constipation, stool frequency and consistency, and straining at stool. Abdominal evidence of faecal loading of the sigmoid colon was noted if present. After explaining the procedure we attempted to elicit reflex anal dilatation by the method of Hobbs and Wynne.' A rectal examination was performed if indicated clinically. When reflex anal dilatation was present the carer was informed and asked whether he or she had any worries about possible abuse.

The table shows details of the children. In none of them was a history of abuse elicited. The youngest child with reflex anal dilatation was 7 weeks old. The anal dilatation varied from $0.5 \mathrm{~cm}$ to $3.5 \mathrm{~cm}$ in diameter. Its presence did not correlate with a history of constipation or the presence of palpable faeces in the abdomen. Despite this, of 18 children with reflex anal dilatation who had rectal examinations, 13 had faeces (hard in three cases) in the rectum. One child with functional megacolon had reflex anal dilatation, which resolved within a week of laxatives being started. Fissures were noted in four children, three of whom were severely constipated, of whom one had reflex anal dilatation. No child passed a stool immediately after reflex anal dilatation was elicited.

\section{Comment}

During the study we and colleagues diagnosed cases of child sexual abuse (some with and some without reflex anal dilatation). Hobbs and Wynne did not find reflex anal dilatation in normal children, but their data
Department of Paediatrics, Selly Oak Hospital, Birmingham B29 6JD A Stanton, MRCP, registrar $\mathrm{R}$ Sunderland, $\mathrm{MD}$, consultant

Correspondence to: Dr Stanton.

BrMed f 1989;298:802-3
Numbers of children $(n=200)$ with and without reflex anal dilatation according to age and clinic attended

\begin{tabular}{|c|c|c|c|c|c|c|c|}
\hline \multirow[b]{2}{*}{ Type of clinic } & \multirow{2}{*}{$\begin{array}{c}\text { Result of } \\
\text { examination } \\
\text { for reflex anal dilatation }\end{array}$} & \multicolumn{6}{|c|}{ Age } \\
\hline & & $<6$ Months & 6-23 Months & $2-4$ Years & 5-9 Years & $\geqslant 10$ Years & Total \\
\hline Community & $\left\{\begin{array}{l}\text { Positive } \\
\text { Negative }\end{array}\right.$ & $\begin{array}{r}1 \\
21\end{array}$ & $\begin{array}{r}1 \\
21\end{array}$ & 31 & & & $\begin{array}{rl}5 & 6 \\
73 & \end{array}$ \\
\hline General & $\left\{\begin{array}{l}\text { Positive } \\
\text { Negative }\end{array}\right.$ & $\begin{array}{l}1 \\
7\end{array}$ & $\begin{array}{r}1 \\
20\end{array}$ & $\begin{array}{r}4 \\
24\end{array}$ & $\begin{array}{r}8 \\
28\end{array}$ & 8 & $\begin{array}{l}14(14) \\
87\end{array}$ \\
\hline Renal & $\left\{\begin{array}{l}\text { Positive } \\
\text { Negative }\end{array}\right.$ & & $\begin{array}{l}2 \\
2\end{array}$ & 3 & $\begin{array}{l}3 \\
6\end{array}$ & $\begin{array}{l}1 \\
4\end{array}$ & 12 \\
\hline Total & $\begin{array}{l}\text { Positive } \\
\text { | Negative }\end{array}$ & $28(7 \%)$ & $\begin{array}{l}\left.+9^{\prime \prime \prime}\right) 1 \\
+3\end{array}$ & $\begin{array}{l}10\left(15^{\prime \prime} w\right) \\
55\end{array}$ & $\begin{array}{l}11(24 \%) \\
34\end{array}$ & $12^{1\left(8^{\prime \prime} 1\right)}$ & $\frac{28}{172}$ \\
\hline
\end{tabular}

